\title{
Significant Failure Factor of Higher Learning Institution Projects
}

\author{
Abdulhameed Rakan Alenezi, Muhammad Salim Javed Gandapur, Arshad Javed, and Moussa Demba
}

\begin{abstract}
The Ministry of Higher Education invests a significant sum of amounts in projects of the higher learning institutions but the success rate is still limited. Majority project continues to fail in achieving their objectives even with a good resource of project management and ultimately get scrapped. The main goal of this study is identification of project failure factors by an examination of higher learning institutional projects. The data were collected from projects of higher learning institutions of Saudi Arabia by conducting interview and distribution of structured questionnaire among project managers. The result showed that procedure for processing of project approval and release of funds has an unfavorable impact on the development project such as poor control, delayed project implementation, and checking system etc. In the same way, when projects are designed to poorly be short of the major characteristics of planning such as objectivity, feasibility, appraisal and detail cost forecasting. Therefore the project deficient a quality management system and bring about the main reasons for project failure. The solution requires a method to evaluate and identify the various significant factors that causes project failure and their mutual association. The validation of the conceptual solution has led to the conclusion that a systematic and holistic approach would improve the overall success rates of project and a project manager would be notified of problems during all phases of project life cycle.
\end{abstract}

Index Terms-Project management, project failure factors, higher learning institutions, risk factors, project planning.

\section{INTRODUCTION}

The project management is a combination of an art and science. The art aspects means working and dealing with peoples while the science aspects means deals with rigid processes associated with project management [1]. The project management has a significant role in the success of any project. It not only ensures that the project is completed in a time and budget using available resources.

Further, estimation of different factors such as cost, time, efforts, safety, reliability and resource requirements are some important factors for project managers as highlighted by different authors in the last few decade literature studies. If project managers have sufficient knowledge in the planning of all such factors during the project development life cycle, he/she will minimize impact of the risk and has full control over the project [2], [3]. An efficient and

Manuscript received February 2, 2014; revised May 20, 2014. The authors indebted to Aljouf University, Saudi Arabia of approval for research under grant no. 33/128 of project title "Development of prediction models for project in higher learning institutions of Saudi Arabia".

Abdulhameed Rakan Alenezi, Muhammad Salim Javed Gandapur, Arshad Javed, and Moussa Demba are with the Faculty of Computer Sciences and Information, Aljouf University Saudi Arabia (Corresponding author e-mail: msjgandapur@yahoo.com). effective estimation of factors not only requires any unyielding technical basis but knowledge of different factors particularly specific to the higher learning institutions. However in a realistic situation, much of information about the previous projects will help in the estimation of project factors, are unknown or uncertain.

The management of an institution usually faces problems in the initial stages of project [4]. The project manager learns a lesson from failure of previous projects. It helps the manager and improves the process of decision making while an error or mistake is a sign of gap in one's knowledge. Learning starts from the identification of a mistake. The manager finds out the solution for its correctness [5]. An error or mistake always provides an opportunity for correction. The project may consider failure, if the result does not match with their objectives as highlighted by different researchers [2]. This study and knowledge is more beneficial to find out the major role of the project factors in failure of a project for all developing countries, policy makers and higher learning institutions with limited resources. The rest of the paper is organized as follows. Section II presents related works; Section III outlines the methodologies of data collection while Section IV presents findings and data analysis along with a conclusion.

\section{RELATED WORK}

The decision making usually depends upon the skill of the project managers. These decisions are made at a time when a great number of factors are invisible and project manager decides the quality of a project just after completion of a project [6]. The Ministry of Higher Education invests significant sums of money in the project of higher learning institutions, yet the success rate remains limited. A recent literature studies conducted by Forrester Research Inc. has shown a comparison of project management in a Table I whose main efforts to reduce the risks associated with the project failure [7].

TABLE I: COMPARISON OF PROJECTS BY FORRESTER RESEARCH INC [7]

\begin{tabular}{|l|l|l|}
\hline Project Failure & Project Cancelled & $\begin{array}{l}\text { Project Delivered } \\
\text { Late }\end{array}$ \\
\hline $66 \%$ & $52 \%$ & $82 \%$ \\
\hline
\end{tabular}

Other literature study states that $5-15 \%$ of the project initiation phase will be unrestrained before or shortly after delivery as completely insufficient. Many other projects will arrive late and over budget or requires massive reworking" [8]. If a project manager fails to manage a project properly, or improve the success rate of the project. It can lead to a variety of problems [9]. The Chaos Report by the Standish 
Group in 1995 has shown in excess of $189 \%$ of their original estimates in Table II.

TABLE II: THE CHAOS REPORT BY THE STANDISH GROUP (1995)

\begin{tabular}{|c|c|}
\hline Project Overruns & Project Cancelled \\
\hline $52 \%$ & $31 \%$ \\
\hline
\end{tabular}

Another research study surveyed over 600 institutions across 22 countries by KPMG International. This study reported that $86 \%$ of the respondents stated the loss of up to a quarter of their targeted benefits across their project portfolios [10]. A survey conducted by KPMG Canada in 1997 sent out 1450 questionnaires to the public and private sector institutions and 176 were analyzed the following report.

TABLE III: A SURVEY CONDUCTED BY KPMG CANADA (1997)

\begin{tabular}{|c|c|}
\hline Project Ahead Schedule & Project Over Budget \\
\hline $61 \%$ & $39 \%$ \\
\hline
\end{tabular}

A Standish Group International has shown a chronological trend analysis report for project success and project failures for the period of 1994 to 2000 and 2000 to 2006 in Fig. 1 and Fig. 2 respectively [11]-[14].

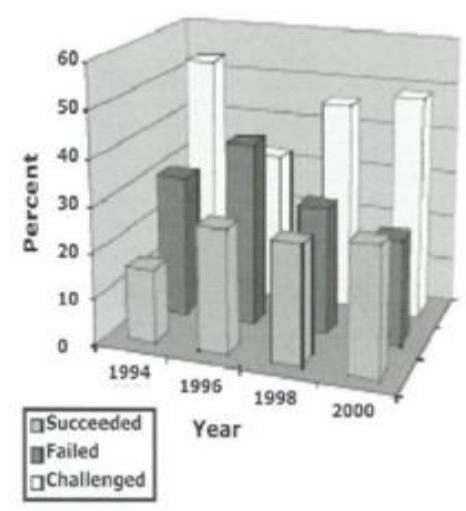

Fig. 1. Project statistics 1994-2000 (by standish group international).

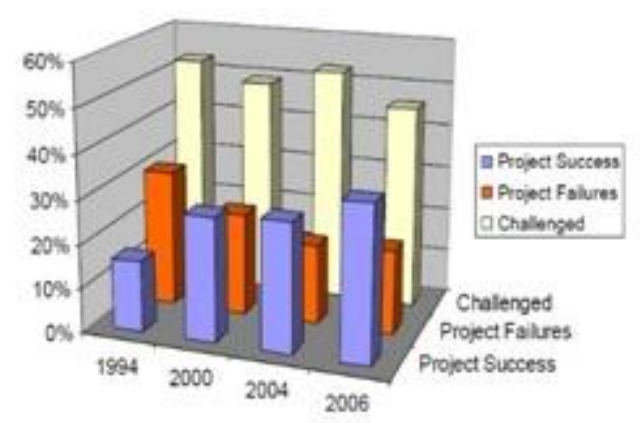

Fig. 2. Project statistics 2000-2006 (standish group international).

The figure shows that the overall project success rate has been increased from 16\%-35\% during the period 1994 to 2006. This improvement was due to extensive usage of sound project management [11]. It also shows that during last eight year those projects which are challenging, are over budget and /or did not meet requirements, are consistently above $40 \%$. Project failures refer to those projects which were cancelled prior to completion, or completed and never used decreased from $31 \%$ to $19 \%$ percent [12]. There is a need for additional information and a research study is required to understand what factors contribute to project failure, and what can be done to increase the probability of project success. Usual research articles on project management have documented significant factors that contribute to project success or failure. In spite of the various methods and techniques for project management that have been developed and documented, "project management remains a highly problematic endeavor" [15]. The survey evaluated 15 projects with inputs have shown in Table IV [16].

TABLE IV: 15-PROJECT SURVEY [16]

\begin{tabular}{|c|c|}
\hline Project Successful & Project Unsuccessful \\
\hline $62 \%$ & $38 \%$ \\
\hline
\end{tabular}

The survey calls attention to the main role of project manager, the level of experience and technical background of the project manager, and the benefit of having a project manager with clearly defined goals and vision as important factors for success. Good schedule and resource estimates also will contribute to project success. This survey evaluated the impact of requirements gathering, requirements management, and cost and effort estimation and scheduling. This article concludes that "the greatest opportunity for improvement is at a project's start, in the requirements and risk identification and control areas" [16]. The Harland study pointed out some of the weaknesses in project planning and design process that affect the project outcome. He drew the following weaknesses in the project planning process [17]. The Blair Witzel study 2006 concentrated on the following factors which causes the main failure of a project [18]:

- Absence of sponsor involvement or support.

- Compressed or unrealistic timelines

- Failure to adequately define

- The project is an enemy of the good Critical Project lists "10 signs of project failure" as:

- Project managers don’t understand users' needs.

- The project scope is ill defined.

- Project changes are managed poorly.

- The chosen technology changes.

- Business needs change.

- Deadlines are unrealistic.

- Users are resistant.

- Sponsorship is lost.

- The project lacks people with appropriate skills.

- Managers ignore best practices and lessons learned" [19]

White, D., Fortune, J., Study report 2007 lists "the most common factors for failure of the project" as:

1) Unrealistic or unarticulated project management goals.

2) Inaccurate estimates of needed resources.

3) Badly defined system requirements.

4) Poor reporting of the project's status.

5) Unmanaged risks.

6) Poor communication among customers, developers and users.

7) Use of immature technology.

8) Inability to handle the project's complexity. 
9) Sloppy development practices.

10) Poor project management.

11) Stakeholder politics.

12) Commercial pressures [20].

The literature review shows that the factor plays a significant role in failure or success of any project. Therefore it was a great need for management of the higher learning institutions to give proper attention to the main significant factors that any type of mismanagement will bring failure to the projects. The current study will therefore focus the same issue.

\section{Methodology}

Data were gathered through personal interviews and distribution of structured questionnaires among project manager of selected 15 public and private sector higher learning institution or faculties of Saudi Arabia. In some cases, returns were via email or phone where such method was required. Under this method, answers were reviewed and a thing was noticed that differences were not so and if it found they were tested again and again.

\section{FINDINGS AND DATA ANALYSIS}

TABLE V: DESCRIPTIVE STATISTICS ANALYSIS OF QUALITATIVE DATA IN

\begin{tabular}{|l|c|c|c|c|}
\hline \multicolumn{1}{|c|}{ Quantitative data } & Max & Min & Avg & $\begin{array}{c}\text { Standard } \\
\text { Deviation }\end{array}$ \\
\hline Project Type & 6 & 1 & 3.13 & 1.74 \\
\hline Delivery System & 2 & 1 & 1.56 & 0.50 \\
\hline Scope Defined & 5 & 2 & 4.20 & 0.95 \\
\hline $\begin{array}{l}\text { Early involvement of all } \\
\text { parties }\end{array}$ & 5 & 1 & 3.66 & 0.86 \\
\hline $\begin{array}{l}\text { Assistance from } \\
\text { Operation }\end{array}$ & 5 & 1 & 4.06 & 0.70 \\
\hline $\begin{array}{l}\text { Role and responsibilities } \\
\text { defined }\end{array}$ & 5 & 1 & 4.05 & 0.98 \\
\hline Communication & 5 & 1 & 3.81 & 1.09 \\
\hline Innovative technology & 5 & 1 & 3.86 & 1.29 \\
\hline Difficulty in approval & 5 & 2 & 4.24 & 0.96 \\
\hline Quality of estimate & 5 & 1 & 3.54 & 0.89 \\
\hline Quality of project team & 5 & 1 & 4.17 & 0.85 \\
\hline Design completeness & 5 & 3 & 4.68 & 0.58 \\
\hline Procurement plan & 5 & 2 & 4.23 & 0.63 \\
\hline Equipment used & 5 & 1 & 4.39 & 1.07 \\
\hline Institution condition & 4 & 1 & 3.08 & 0.73 \\
\hline Site condition & 5 & 1 & 3.58 & 1.40 \\
\hline Weather & 5 & 1 & 3.58 & 1.25 \\
\hline
\end{tabular}

The result shows that a project can't fail on account of one or more hidden factor. All projects have diverse problems and many of factors are associated with each other's. These findings identified factors contributed in failure of a project has shown in Table $\mathrm{V}$.

This study starts with an aim of the implementation project. The literature study gives some untested and unstructured recommendation. The proposed recommendation is divided into three (3) groups.

- Management techniques considered in project implementation of successful institutions, but used less or not at all at unsuccessful intuitions.

- Practices considered being more essential to success but which did not differentiate between successful projects and unsuccessful projects. These factors may be necessary for success of the project but do not appear sufficient to guarantee of success project implementation.

- Management practices supported in the literature studies but not supported in the case studies.

A simple descriptive analysis was also carried out to gain general information. For the subjective data, descriptive statistical analyses were performed to determine the typical response and distribution of responses, which is shown in Table V. This was to determine whether the collected information would cover all possibilities as thoroughly and consistently as possible. The results showed the examples covered marginally a variety of significant cases in project context.

TABLE VI: TOP TEN RISK FACTORS IDENTIFIED BY SEVEN RESPONDENTS

\begin{tabular}{|c|c|c|c|c|c|c|c|c|c|}
\hline \multirow{2}{*}{ Risk Factors } & \multicolumn{7}{|c|}{ Top 10 factors } & \multirow{2}{*}{ 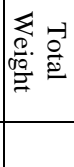 } & \multirow{2}{*}{ 䒕 } \\
\hline & \#1 & $\# 2$ & $\# 3$ & $\# 4$ & $\# 5$ & \#6 & \#7 & & \\
\hline $\begin{array}{l}\text { Effort made in } \\
\text { front end }\end{array}$ & 2 & 3 & 2 & 7 & 1 & 1 & 3 & 58 & 1 \\
\hline $\begin{array}{c}\text { Effort made in } \\
\text { detail } \\
\text { engineering }\end{array}$ & 3 & 7 & 6 & 8 & 6 & & 10 & 22 & 9 \\
\hline Scope defined & 1 & 2 & 1 & 1 & 3 & 3 & 9 & 57 & 2 \\
\hline $\begin{array}{c}\text { Early } \\
\text { involvement of } \\
\text { all parties }\end{array}$ & 4 & 6 & 3 & 6 & 2 & 2 & 2 & 52 & 3 \\
\hline $\begin{array}{c}\text { Assistance from } \\
\text { operation }\end{array}$ & 5 & 8 & 5 & 9 & 8 & 7 & 4 & 25 & 6 \\
\hline $\begin{array}{c}\text { Role and } \\
\text { responsibilities }\end{array}$ & 9 & 4 & 8 & 10 & 10 & 6 & 5 & 23 & 8 \\
\hline Communication & 6 & 5 & 7 & 4 & 4 & 5 & 6 & 40 & 5 \\
\hline $\begin{array}{l}\text { Quality of cost } \\
\text { and schedule } \\
\text { estimate }\end{array}$ & 10 & 10 & 4 & 2 & 7 & 10 & 8 & 25 & 7 \\
\hline $\begin{array}{l}\text { Quality of } \\
\text { project team }\end{array}$ & 7 & 1 & 9 & 3 & 5 & 9 & 1 & 42 & 4 \\
\hline $\begin{array}{l}\text { Design } \\
\text { completeness }\end{array}$ & 8 & 9 & 10 & 5 & 6 & & 7 & 19 & 10 \\
\hline
\end{tabular}

The top ten (10) risk factors were identified in Table VI that was ranked by seven (7) respondents individually in the survey. The ranks were given according to the significance, based on the practitioner's knowledge and experience in relevant field. The response value for each of these items was required to reverse before summing for the total. It was 
calculated with a simple formula as:

$$
\text { New value }=(\text { High value }+1)=\text { Old value }
$$

In this case, the high value was ten (10). Thus, the overall rank was obtained according to total weight (TW), which was defined as follows:

$$
\mathrm{TW}=\sum_{j=1}^{7}\left(11-x_{i j}\right)
$$

where $X_{i j}$ represent rank given to the $i($ th) risk factor by individual $j$.

The research methodology approach based on questionnaire and interview revealed that the procedure for project processing, approval and fund release procedures has adverse effect on the development project in the form of delayed project implementation, poor control and checking system.

Similarly when projects are designed poorly, lacking major aspects of planning such as objectivity, feasibility, appraisal and detail cost forecasting. Monitoring and assessment of the projects are not appropriately conducted, nor is any critical attention given to it during all phases of the project development life cycle. Therefore the project lacked a quality management system and causes main reasons for failure in the project.

However changes in project objective, scope, design and priorities, poor utilization of management techniques, mismanaged annual plan of operation and diluted resources committed to projects cripple the situation badly affecting the performance of a project.

\section{CONCLUSION}

The resulting analysis shows that a project can't fail on account of a single factor but fail for multiple reasons. These findings are in full agreement with the Glass [13], [14]. These also improve the findings reported by Charette [8], Yardley [21] and Glass [22]. It also covers most of the factors reported in the project study reports [23], [24].

This paper is a focal point to find the factors for failure of a project. In spite of this, also identifies hidden factors for bad performance. The management needs to give notice to the points that any type of mismanagement of project factors brings failure to the projects. One of the major criteria for project success identified by this study is the fit between the project objectives and that of the higher learning institutions and the impact of the project performance. This study clearly indicates that the project must address the processes and objectives and there must be alignment between objectives and project deliverables. Other top ranking factors respondents identified as critical to project failure mirrored the typical criteria of unrealistic schedule, inadequate funds and resources, unclear objectives and nonsupport from senior management. The study concludes that there needs to be "a greater understanding of the effects of the various interacting and associated processes and decisions that take place throughout the life of a project, thus building up a more holistic view of project management.

However, it is pertinent to point out that although researchers did study different factors but no such system has not yet been developed through which all such proven factors could be brought under one system of management, thus making easier for managers to decide upon the inclusion or exclusion of factors into a specific project environment.

\section{ACKNOWLEDGMENT}

We thank all participants in the tedious and hectic collection of questionnaire and conduction of interview from Project Manager(s) of Higher Learning Institutions of Kingdom of Saudi Arabia.

\section{REFERENCES}

[1] W. J. LaMarsh, "Investigating the relationship between an IT project managers emotional services and customer perceptions of success," PhD thesis, Old Dominian University, 2009.

[2] R. L. Ackoff, "It's a mistake!" Systems Practice, vol. 7, pp. 3-7, 1994.

[3] F. T. Hartman, "Rules of thumb," presented in Project Planning and Control Course, Canada, 1998.

[4] J. Fortune and G. Peters, "Learning from failure: The systems approach," John Wiley \& Sons, 1997, pp. 1-278.

[5] D. F. Cooper, S. Grey, and G. Raymond, "Project risk managemen guidelines: Managing risk in large projects and complex procurements," Broadleaf Capital International: J. Wiley, West Sussex, England; Hoboken, NJ, 2005.

[6] M. S. J. Gandapur, A. K. B. Mahmood, and S. B. Sulaiman, "An assessment of parameters affecting projects of regional public sector universities Pakistan," in Proc. 2012 International Conference on Computer and Information Scerinces (ICCIS), Kuala Lumpur Malaysia, 2012

[7] Failure. (March 2003). [Online]. Available: http://www.workstar.net/library/pm1.htm

[8] R. N. Charette, "Why software project fails," IEEE Spectrum, pp. 42 49, Sept. 2005.

[9] L. Wallace, M. Keil, and A. Rai, "Understanding software project risk: A cluster analysis," Journal of Information and Management, vol. 42, no. 1, pp. 115-125, March 19, 2004.

[10] K. Hollaway, "KPMG Highlights IT project failures," Accountancy Age, Nov. 25, 2005.

[11] W. S. Humphrey, "Why big software projects fail, The 12 key questions," Journal of Quality Assurance Institute, vol. 18, no. 3, pp. 30-36, 2005

[12] J. Liao, "Failure is not an option," PM Network, vol. 21, no. 6, pp. 8 10, 2007.

[13] R. L. Glass, "IT failure rates- $70 \%$ or $10 \%-15 \%$," IEEE Software, vol. 22, no. 3, pp. 112-113, 2002.

[14] R. L. Glass, "Failure is looking more like success these days," IEEE Software, vol. 19, no. 1, pp. 104-106, 2005.

[15] D. White and J. Fortune, "Current practice in project management an empirical study," International Journal of Project Management, vol. 20, no. 1, pp. 1-11, 2002.

[16] J. Verner and W. Evanco, "In-house software development: What project management practices lead to success?" IEEE Software, vol. 22, no. 1, pp. 86-93, January/February 2005.

[17] B. Harland, O. M. Jan, V. Krepl, K. Srnec, and P. Kapila, "Projects and planning," Czech Agricultural University, Prague, the Czech Republic, pp. 56-60, 2001.

[18] B. witzel, "Four reasons for project failure," A Report on Project Management, March 6, 2006.

[19] J. S. Reel, "Critical success factors in software projects," IEEE Software, May/June, 1999.

[20] D. White and J. Fortune, "Current practice in project management an empirical study," International Journal of Project Management, vol. $20,2007$.

[21] D. Dalcher and L. Brodie, "Successful IT projects," Thomson Learning, Middesex University Press.

[22] R. L. Glass, Software Runaways, Prentice-Hall, New York, 1998.

[23] P. C. C. Albert, D. Scott, and P. L. Chan. "Factors affecting the success of a construction project," Journal of Construction Engineering and Management," vol. 130, no.1, pp. 153-155, 2004.

[24] T. C. L. Aaren, "Predicting the performance of design-bid- build projects: A neural-network based approach," Master project report, Universiti Teknologi Malaysia, Malaysia, 2006 


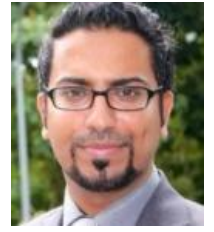

Abdulhameed Rakan Alenezi is currently the dean of Faculty of Computer Science and Information, Aljouf university, Saudi Arabia. He received his PhD degree in 2008 from University Utara Malaysia with major elearning. His research interests are e-learning, project management etc.

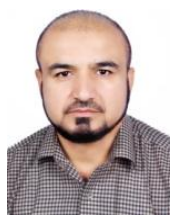

Muhammad Salim Javed Gandapur is currently a $\mathrm{PhD}$ off-campus student at University Technology PETRONAS Malaysia as well as staff member of Aljouf University, Saudi Arabia. He received his master degree of computer sciences in 1990 from University of Peshawar, Pakistan. He also received his master degree executive master of business administration in 2005 from University of Malakand, Pakistan. His research interest includes software engineering, project management and artificial intelligence.

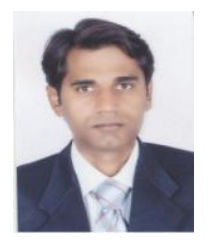

Arshad Javed was born in 1977 and is currently a PhD student at University Malaysia Sarawak, Malaysia. He received his master degree in 2003 in computer science from Quaid-e-Azam University Islamabad, Pakistan. His research interests are image processing, software project management, algorithms.

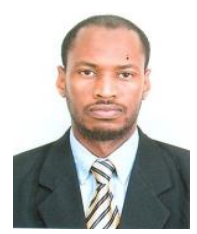

Moussa Demba was born on Feb. 1, 1972 and currently is an asstt. professor at the Faculty of Computer Science and Information Technology, Aljouf University, Saudi Arabia. He received his Ph.D. in software engineering 2006. His research interests include program verification, logic program synthesis, database systems, artificial intelligence and e-learning. 